\title{
ACRL Interns Selected
}

The Association of College and Research Libraries, a division of the American Library Association, has announced the selection of six interns to participate in the fourth year of its program for administrators of predominantly black college and university libraries. The program, funded by a grant from the Andrew W. Mellon Foundation, is intended to accelerate the development of the management ability of librarians in black colleges and universities by providing them with experience in the administration of strong and progressive academic libraries.

The six fourth-year interns are: Virgia BrocksShedd, reference-serials librarian, Tougalon College, Tougaloo, Miss.; Alma Dawson, head periodicals librarian, Prairie View A \& M University, Prairie View, Tex.; Doris M. Gosier, head, public services, Fort Valley State College, Fort Valley, Ga.; George M. Martin, librarian, Social Science Reading Room, Howard University, Washington, D.C.; Millie $M$. Parker, head librarian, Paine College, Augusta, Ga.; and Jean Frances Williams, acquisitions librarian, Virginia State College, Petersburg, Va.

During the period of the six-month internship, each intern will work closely with the director of a major academic library. The host institutions for the fourth year of the program are: Mount Holyoke College, Oberlin College, the University of Wisconsin-Milwaukee, and Virginia Commonwealth University. The Mellon Foundation grant provides salaries, benefits, and approved expenses for each intern. The host library provides the training experience. Several workshops for the participants also are planned.

Applications from librarians and prospective host institutions were reviewed by the project's advisory committee, chaired by Virginia Lacy Jones, dean, School of Library Service, Atlanta University. Other members of the committee are: Phyllis B. Cartwright, Florida International University, Miami; Richard M. Dougherty, University of California, Berkeley; Beverly P. Lynch, University of Illinois at Chicago Circle; James F. McCoy, Hudson Valley Community College, Troy, N.Y.; Annette L. Phinazee, School of Library Science, North Carolina

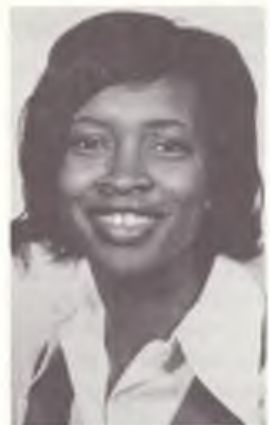

Alma Dawson

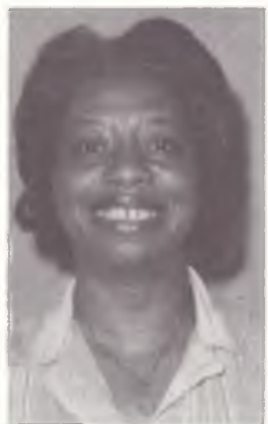

Millie M. Parker

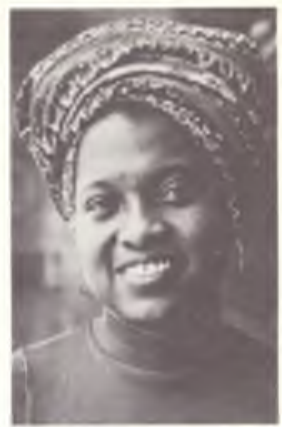

Virgia Brocks-Shedd

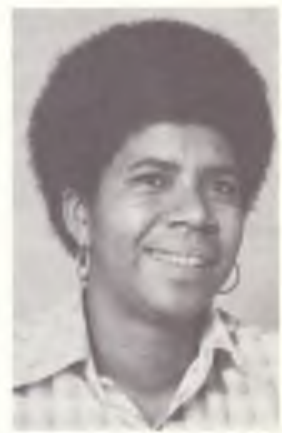

Doris M. Gosier

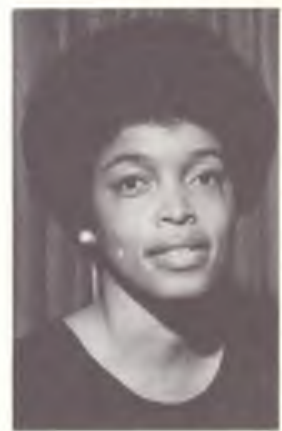

Jean Frances Williams 